\title{
On the Comparative Study of Corruption*
}

\author{
Franklin E. Zimring** and David T. Johnson***
}

\section{TABLE OF CONTENTS}

I. Comparative CRIMINology: NeCESSITY AND PromisE........................... 244

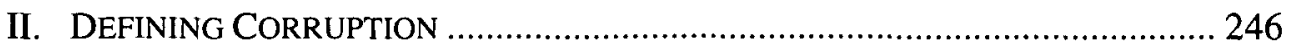

A. Bribery and Corruption.................................................................. 247

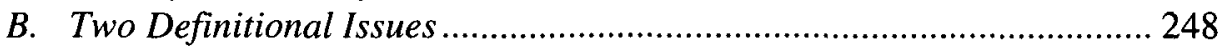

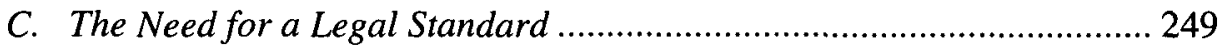

D. Necessary Versus Sufficient Conditions ............................................. 250

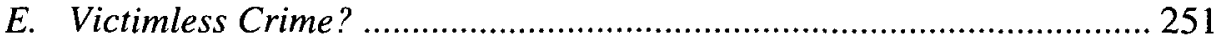

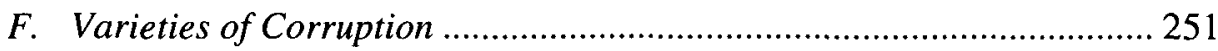

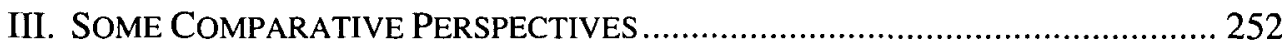

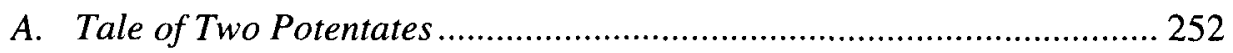

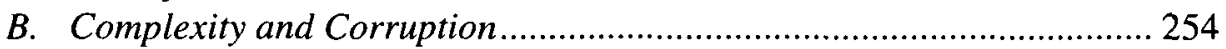

C. Complexity and Types of Corruption …………….............................. 256

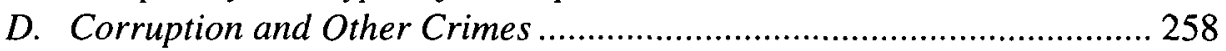

IV. CORRUPTION AND THE PROBLEMATICS OF WhITE-COLLAR CRIME ........... 259

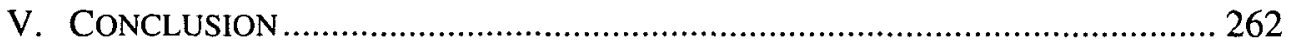

This essay has two ambitions. The first is to show that a transnational comparative perspective can be of value in identifying topics worth studying in criminology and criminal law as well as an important method of conducting such studies. The second aim is to use the comparative perspective and method to explore the topic of corruption, a pervasively important and distinctive behavioral phenomenon that is of critical importance in both developing and developed nations. A comparative perspective on corruption provides insight about the role of this peculiar form of crime in various cultures and stages of development. Moreover, we also believe that a focus on corruption as a special category of crime helps to explain the passions and politics that have been involved in discourse on white-collar crime.

* This article has been previously published in the British Journal of Criminology (Franklin E. Zimring \& David T. Johnson, On the Comparative Study of Corruption, 45 BRITISH J. CRIMINOLOGY 793 (2005)). We thank the following for helpful commentary: Susan Rose-Ackerman, Richard Leo, Henry Pontell, Michael Tonry, Andrew Von Hirsch, José Luis Díez Ripollés, and the participants in the eighth annual Nigel Walker Lecture at Cambridge in May of 2004.

** Boalt Hall, School of Law, University of California, Berkeley.

*** Department of Sociology, University of Hawaii and Criminal Justice Research Program, Boalt Hall, School of Law, University of California, Berkeley. 
We begin our tour with a plea for the increasing value of comparative study as a tool for criminological agenda setting and research. A brief second section defines corruption as a special subcategory of criminal behavior defined as the unlawful use of power. A third section then speculates on the relationship between corruption and features of social and governmental organization. A final section applies this comparative perspective to some longstanding issues in criminological discourse. We show that the same mix of condemnation and imprecision that has frustrated efforts to define white-collar crime produces ambiguity in the definition of corruption. We also suggest that the core focus of our criminology of corruption - the use of power as an instrument of crime-also helps to explain why white-collar crime has evoked concern, particularly among criminologists on the left. The unifying substantive theme in this analysis is the view of corruption as the criminal misuse of power.

\section{COMPARATIVE CRIMINOLOGY: NECESSITY AND PROMISE}

In the early years of the 21 st century, there are two important respects in which citizens of most regions are living on a smaller planet than a generation ago. First, the impact of problems in one place upon conditions in other places is more pronounced and faster in the current era than ever before. Whether the particular event is a bond default in Moscow, avian flu virus in China, political repression in Burma, or unemployment and low birth rates in France, the swift impact of many events far from their origins has become a commonplace observation of those who study globalization in culture, politics, public health, and economics.

The second aspect of globalization worth mention is the more rapid contagion of promising innovations in both the private and public sectors of institutional activity. With frequent travel and multinational business entities, both the lapsed time before innovations are transferred and the chances of transfer have increased to an extraordinary degree. So if the first impact of globalization is a larger susceptibility to problems, the second impact may be the faster transmission of solutions to problems. There is no indication in current shrinkage of the globe that the homogenization of commerce and speed of communication will soon end major differences in society and government, but a pervasive environment of mutual influence is a broad and important part of current events in most fields.

Criminology is no exception. International exchanges and organizations are proliferating in the developed world, including a new European association and international collaborations among scholars and organizations. Multinational research projects have included written surveys with common questions and estimation techniques that were published in the mid-1990s for a variety of 
developed nations', followed by an attempt to measure victimization by survey in less developed nations. These findings have already been integrated in some discussions of transnational risks of crime and violence. ${ }^{2}$ There have also been more limited international comparisons of criminal case processing and case outcomes. ${ }^{3}$ Such efforts are in their pre-history, with much more work and greater sophistication to be anticipated in a relatively short time.

Two comments on the promise of comparative criminology here deserve emphasis. First, the value of comparative work is not simply to document differences and similarities between countries and systems, for the comparative perspective is also a valuable tool for analyzing the distinctive character of one's own domestic practice and policy. The special character of life-threatening violence in the United States, for example, is nowhere more apparent than in cross-national comparisons demonstrating that broadly similar rates of nonviolent and even non-lethal violent crime exist among nations, whereas rates of lethal violence differ markedly. ${ }^{4}$ So the value of comparison is much greater than its utility for describing observed variations between states and societies. It is an essential device for understanding what is distinctive (and problematic) about domestic arrangements. ${ }^{5}$

The second point about the promise of a comparative perspective is that the incentives to conduct comparisons are not evenly distributed throughout developed nations. Those who live in small countries are more easily convinced of the necessity of comparative work than those who live in big countries, if only because national variation is a much more visible element in Switzerland or Australia than in the United States. ${ }^{6}$ Yet the value of comparisons in illuminating domestic problems is just as important for big countries as for small ones. If this is right, then there may be a special need to promote and illustrate the domestic

1. See, e.g., J.N. Van Kesteren, P. Mayhew \& P. Nieuwbeerta, Criminal Victimisation in SEVENTEEN INDUSTRIALISED COUNTRIES:, KEY-FINDINGS FROM THE 2000 INTERNATIONAL CRIME Victims SuRVEY (2000) (issued by the Hague, Ministry of Justice).

2. F. ZimRing \& G. HAWkins, CRime Is Not THE PROBlem: Lethal Violence in AMERICA, ch. 3 (Oxford University Press 1997).

3. See, e.g. P.A. Langan \& D.P. Farrington, Crime and Justice in the United States and in England and Wales, 1981-96. Washington, D.C.: U.S. Bureau of Justice Statistics (1998).

4. ZIMRING \& HAWKINS, supra note 2, at ch. 3.

5. J.H. Langbein, The Influence of Comparative Procedure in the United States, 43 AM. J. COMP. L., 545-554 (1995); S. LiPSET, AMERICAN EXCEPTIONALISM: A DOUble-EdGED SwORD (W. W. Norton New York1996).

6. American criminology is provincial. In Criminology, the flagship journal for the American Society of Criminology, just 7.4\% of articles published between 1990 and 1999 had "any kind of international/ comparative focus". See R. Barbaret, Global Competence and American Criminology: An Expatriate's View, 26 CRIMINOLOGIST at 1, 3-5 (2001). For the same period, the Australia and New Zealand Journal of Criminology published 190 articles, of which $11 \%$ were international or comparative, by our standards still a low figure even if it is $50 \%$ higher than the parallel American figure. American law and society scholarship is also provincial. Between 1966 and 2000, for example, Law \& Society Review published 352 "original research" articles, of which only $23(6.5 \%)$ can be called "comparative analysis". See S. Silbey, From the Editor, 34 LAw \& SOCIETY REVIEW at $859-871$ (2000). The analogous figure for $1990-2000$ was $6.6 \%$. 
values of comparative methods in the United States. The less natural a comparative perspective seems in the study of social behavior, the greater the chances that errors are made and opportunities for understanding are missed because of its absence. Similarly, the more students of a system assume its own uniqueness, the easier it will be to avoid evidence of non-uniqueness and the harder it will be to identify differences that are dysfunctional and problematic. The assumption of uniqueness thus frequently defeats opportunities to study how American behavior and institutions are exceptional. ${ }^{7}$

This preliminary essay explores the value of a comparative perspective in thinking about corruption as a distinct and widely present type of behavior that is criminal in a wide variety of complex societies. We first define that term and illustrate the distinctiveness of the category of behavior and the importance of the phenomenon as an impediment to economic development and social justice. We then apply the perspective obtained from a comparative approach to an analysis of white-collar crime as the criminal misuse of social or economic power.

\section{DEFINING CORRUPTION}

Rather than constructing a definition of the crime of corruption in isolation, we wish to seek a definition of this particular offense in the context of the other types of methods of obtaining property that are usually considered criminal. By situating a definition of corruption in this larger tapestry, we hope to keep the distinctions between types of crime clear and to maintain consistent criteria for what makes violations of the interests of persons or institutions criminal.

In the criminal law there are at least four different methods of wrongfully obtaining control over the property or personal interests of others. One recurrent threat is the thief or burglar who takes by stealth, removing property when owners and custodians are not looking. A second method of victimization is to obtain property or compliance by use or threat of unauthorized personal force. "Your money or your life," is the choice the robber seeks to impose on his victim without any legal authority to use force. A third class of criminal methods involves the use of fraud or falsity to induce victims to part with things of value because they believe facts the offender has misrepresented to them. Frauds and confidence games are as old as recorded history but as contemporary as the hundreds of millions of emails sent out by persons purporting to have access to Nigerian bank millions, but who require the assistance of "honest citizens" to secure mutual riches.

The fourth method of obtaining control over the property or person of another is the use of social or institutional power. When power granted to persons for restricted purposes is used instead for unauthorized personal aims, unlawful

7. Assumptions of singularity that have been tested-such as the views that America is a "high crime society" or that American criminal justice is uniquely characterized by "leaky pipe" caseload attrition-often prove to be false. 
and socially wasteful exchanges take place: the government official charged with selecting the most qualified firm to provide trash collection to the city instead selects the firm that offers him the most money in a personal bribe or as a "contribution" to a non-governmental organization; the school teacher with the power to assign grades on a merit basis to student work instead trades high grades for cash or personal favors from students or their families; the company official with the power to sell property for the benefit of the firm gives a major price concession to a buyer in exchange for a personal payment; the president of a nation grants public licenses that are not supposed to be given away to his friends and family rather than auctioning them off and making the proceeds available to the common good. In all these cases, the offender has power for limited purposes and uses the power in prohibited ways.

While acts of corruption, which we define as the illegal use of power for personal gain, are no less or more dishonest than crimes involving force or stealth, the social structure of corruption and its distribution in society are different from crimes of personal force, fraud, or stealth. Anonymous acts of force or secret-taking are typically acts of persons who lack social or government power. In contrast, corruption is, by definition, an act of a person who has either the economic power to bribe another or the power to provide a favor for a bribe. Thus, corruption is a crime of the powerful, even though the power that triggers corrupt acts may often be minor and special-purpose. Traffic cops, sixth-grade teachers, and those who audit the tax records of small businesses are by no means potentates, but they do hold special-purpose authority of great importance.

\section{A. Bribery and Corruption}

What makes a bribe into a crime rather than a legitimate exchange of money for value or a gift? The answer to this question has been another source of uncertainty and complexity in penal theory. ${ }^{8}$ We define a bribe as the payment for a corrupt act, making the wrongfulness of the payment depend on the forbidden nature of the consideration for the payment. As long as the favor provided should not be exchanged for money, the act is corrupt and the payment for it should be considered a bribe. There may exist in local law specific prohibitions on selling discretionary power where the only unlawful use of the power is the acceptance of money itself. This type of "per se" corruption rule might seem to challenge the derivative nature of our definition, but we do not think the fact that it is the offering of money that makes the use of power wrongful undermines the utility of our definitional approach. Even here, it is the power holder's deviation from legal regulations constraining his acts that makes the transfer of money or other favors in exchange for benefits into a forbidden act.

8. See J.T. NOONAN JR., BRIBES (Macmillan 1984). 


\section{B. Two Definitional Issues}

Once the distinguishing feature of corruption is seen as the abuse of power, the next important question concerns the breadth of abuses of power to be regarded as corrupt. One definition would restrict the concept's scope to the unlawful use of power for personal gain or other personal objectives, thus limiting corruption to the venal and self-serving acts, which are the archetypical illustrations of graft and bribery. In settings such as the break-in of psychiatrist Daniel Ellsberg's office during the Nixon years, when national security powers were misused for a conception of governmental interest, or in the Iran-Contra case, where illegal exchanges were made to advance the government's political interests without personal gain, a definition of corruption that requires personal benefit would exclude such acts from being considered corrupt, while a definition of corruption that spanned the unlawful use of power for all purposes would clearly include such acts. The question-on the scope of the abuses of power that should be called corrupt-is a close one. Our position is that the element of personal gain should probably be required, but would include more in the concept of personal gain than money or tangible property.

A second question is easier to resolve: Should unintended abuses of power be considered corrupt? A totally objective standard of when power is unauthorized seems an unjust and therefore unnecessary element of the definition of criminal corruption. Where honest mistakes can be made about the scope of authorized power, such errors should not be regarded as criminal, and, therefore, should not be considered corrupt. Mistakes of this sort might well produce civil liability, but they are not properly blameworthy in the criminal law and should not be regarded as crimes. In our view, the proper mens rea for corrupt abuse of power should be the Model Penal Code's notion of recklessness, and the criminological category of corrupt behavior should also be restricted to purposely unlawful uses of power.'

The usefulness of our definition of corruption can best be explored by comparing it with its competitors. Although the last decade of the 20th century witnessed more publications on corruption than any previous period, key conceptual and definitional questions remain "largely ignored". ${ }^{\circ}$ On the one hand, corruption is such a deeply contested concept that a coherent theory of it "has never been fully articulated"." On the other hand, "there is considerable overlap between various components of proposed definitions". ${ }^{2}$ All analysts agree that corruption involves a deviation from certain standards of behavior. The key question, therefore, and the pivot around which conflict revolves, is what

9. See American Law Institute, Model Penal Code (American Law Institute 2003).

10. A. Heidenheimer and M. Johnston, eds., Political CoRruption: Concepts and ConteXts, xiii (2002).

11. See id. at 5 .

12. See id. at 13 . 
criteria to use in establishing those standards. There seem to be three main candidates: law, public interest, and public opinion. ${ }^{13}$

The legal approach defines corruption in terms of the criteria established by official statutes and judicial interpretation. Thus, an act is corrupt if it is prohibited by laws, and if it is not prohibited it is not corrupt, even if it is unethical or abusive.

The public interest approach focuses on the effects of an act rather than on its legal status. Under this view, if an act is harmful to the public interest, it is corrupt even if it is legal. Conversely, if an act benefits the public, it is not corrupt even if it violates the law.

Public opinion is the third source of criteria that has been used to define standards of integrity. This approach posits that an act is corrupt if some public defines it as such. Since public opinion may vary, analysts in this school must attend to the differences between "black," "grey," and "white" corruption. ${ }^{14}$ "Black corruption" exists when a majority of both elite and mass opinion condemn it and want to see it punished. In contrast, "grey corruption" indicates that some observers, usually elites, want to see the action punished, while others do not-and the majority may be ambivalent. "White corruption" is corruption that is tolerated by the majority of both elite and mass opinion; neither want to see the conduct punished.

Entering the contest to define corruption requires assessing the usefulness of these competing definitions. Because variations in definition affect research and law enforcement-not to mention democracy and development-we believe that definitional questions should be decided based upon criteria of utility. In our view, law provides the most useful standard in terms of how corruption should be defined.

\section{The Need for a Legal Standard}

Only a legal standard can provide a definition of corruption that qualifies both analytically and morally as a crime, and thus allows us to compare offenses of corruption with those of stealth, fraud, or force. Reserving the label of corruption only for acts that appear to the observer to have resulted in substantial social harm is both too broad and too restrictive. If any failed economic policy is harmful to the public, are all those policies that produce more harm than good to be judged, after the fact, as corrupt? Calling lawful acts corrupt when there is no intent to do harm is senseless. Conversely, a harm-centered definition is also too narrow because why should graft and self-dealing that doesn't produce any obvious victims be exempted from blameworthiness?

13. See J. SCOtT, Comparative Political Corruption (1972); and J. Gardiner, Defining Corruption, in A. Heidenheimer and M. Johnston, eds., Political Corruption: ConCepts and Contexts 25-40 (2002).

14. See HEIDENHEIMER AND JOHNSTON, supra note 10. 


\section{7 / On the Comparative Study of Corruption}

\section{Necessary Versus Sufficient Conditions}

Similarly, while a standard based on public opinion rather than legality provides some notice of wrongfulness if public opinion is stable, it provides no social protection in those environments where illegal self-dealing is most rampant because it is tolerated by local mores-even though the behavior is unlawful.

There turns out to be no principled argument against making the unlawful use of power into a necessary element of the concept of corruption. Thus, no use of power may be simultaneously authorized by law and called corrupt. In adhering to this as an ironclad requirement there is the loss only of "corrupt" as an adjective of derision for condemning some forms of undesirable behavior. Given the many other negative terms available in modern languages for denouncing bad policies, this appears to us to be no great loss.

Still, should all unlawful uses of power be regarded as corruption? We have already excluded accidental illegality from the scope of our concern. Should there also be some de minimis exemption for acts that are not obviously harmful? We think not, because of the consequences that one faces if the sine qua non requirement of corruption is either a violation of "public interest" or the presence of critical "public opinion." If the behavior was unlawful, why need we prove that this led to bad results any more with bribery than with larceny by stealth or deception? Even worse would be requiring that corrupt acts be condemned by public opinion other than merely by law, for this would have the effect of minimizing the rate of formal corruption in precisely those settings where the unlawful use of power is the greatest problem.

Rather than making ill repute or bad outcome a requirement of the actus reas of corruption, the law can provide two affirmative defense-style exclusions to the solely legal definition of corruption (in addition to the defense described earlier: the lack of intent to violate the law). The first would exclude from corruption acts where the actor's deviation from legal standard was objectively trivial. The second would provide an exclusion when the illegal use of power was justified by the greater harm avoided or the greater good achieved in a particular case. This second exception would be narrow and rarely successful-as in the exclusion from the category of corruption of illegal conduct by immigration officials to avoid Nazi internment policies. It would not become a standing invitation for political figures to justify broad programs of law violation. ${ }^{15}$

Because the opportunity to be involved in corruption is positively associated with increased power, corruption is one category of crime where the strong will prey on the weak and where the net effect of many acts of corruption may be regressive rather than redistributive of income. In many, if not most, settings

15. See, AMERICAN LAW InStitute, MODEL PENAL CODE $\$ 3.02$ (American Law Institute 2003), discussing the theme of the defense of necessity. 
where corruption flourishes, the offense pattern produces greater rather than lesser concentrations of wealth among advantaged populations.

\section{E. Victimless Crime?}

Because corruption frequently involves an exchange where the immediate parties to a transaction all gain from the unauthorized use of power, many corrupt acts lack a self-defined victim willing to report the conduct to law enforcement authorities. This fact distinguishes corruption from crimes such as larceny, burglary, or robbery in which there are often angry victims. Further, since it is only the unauthorized use of power or its benefits that is regarded as wrongful, the criminal law of corruption is highly sensitive to legal and cultural factors that distinguish authorized from unauthorized motives and effects of discretionary choices by persons in authority. Although a particular state may have a few cultural or legal rules that vary the normal boundaries between illegal and lawful force or claim of right to property, questions of local law and custom will far more frequently be important in dividing permitted from prohibited uses of power in cases of alleged corruption. In short, local variations in law and culture will often be important in deciding whether conduct is corrupt.

Local customs and mores may also fail to condemn some acts of corruption because an obviously harmed individual victim is not present. Thus, even when local law makes the criminality of conduct clear, local morals may all but excuse it.

Although the settings and practitioners of corruption will vary widely-from petty officials to presidents, and from trivial material advantage to treason-there are also systemic differences between corruption and other forms of crime. Practitioners of corruption have power or money or both, and are thus more likely to be of high or middle status than most of the burglars or robbers identified in modern states. The combination of higher status offenders and the frequent lack of a direct victim to complain makes acts of corruption much harder to detect and prosecute than crimes with complainants.

\section{F. Varieties of Corruption}

As we define it, the essential element of corruption is the abuse of power, yet there are a wide variety of forms of corrupt behavior that ought to be distinguished. One distinction relates to the types of power abused-public or governmental power versus private power. The violation of public standards usually threatens the government or the collective benefit of its public as the interest diminished by corrupt acts. In contrast, private corruption involves the abuse of power by those given power over private interests, who advance their own interests at the expense of the owner's interests. Accepting a bribe to avoid collecting a tax is an uncomplicated case of public corruption. An agent who sells private property to a friend for less than the market price is a case of corruption 


\section{7 / On the Comparative Study of Corruption}

with a private victim.

A second important distinction is between predatory and cooperative offenders. Specifically, the predatory offenders seek to keep, rather than share with those they solicit, all of the gains from an unauthorized transaction, whereas the cooperative offenders try to create a natural alliance with those who need the benefits of the power they possess by creating a better outcome for them as well as for the primary offender. The cooperative pattern produces a more stable relationship that is harder to discover and stop. It is associated with social popularity and not infrequently with political power. The predatory pattern does not produce stable long-term relationships unless its victims and customers fear the power-holders. Moreover, the predatory pattern of corruption may often be mixed with uses of force as well. Where there is such a mixture, the charges exacted by the unauthorized users of power may exceed the costs of services in non-corrupt settings.

One final distinction in modes of corruption is between instrumental and affective motivations for participation in corrupt uses of power. In instrumental settings, one type of power is exchanged for other types, typically an exchange of favors for money. What the power-holder wants with the money is not obvious in the exchange. By contrast, in an affective misuse of power, the primary motive of the authority is often that the benefit be conferred on a family member, loved one, or some other person whose gain is the primary motive of the power-holder. On some occasions, power may be misused simply to assert the offender's ability to do so. While the misuse of power for affective purposes may be a violation of social norms, loyalty to family or friends may itself be a socially approved value. Thus, a decision that must sacrifice either standards of probity in using power or loyalty to friends or family can generate value conflicts. ${ }^{16}$

\section{SOME COMPARATIVE PERSPECTIVES}

\section{A. Tale of Two Potentates}

Joseph Mobuto, the late and unlamented president of a nation he chose to call Zaire, and King Fahd Bin Abdul Aziz of Saudi Arabia were two of the richest and most free-spending figures in the ostentatious last decades of the 20th century. Both were notorious for throwing money at projects with no apparent social purpose in a world full of hunger and poverty. King Fahd built a replica of the White House in the hills outside Marbella on the Costa del Sol in Spain. President Mobuto spread billions of dollars over European capitals and Swiss

16. A fourth distinction, between bribery and extortion, has an extensive academic pedigree, but it seems less conceptually and practically important than the distinctions we make here. Our distinction between predatory and cooperative corruption is not parallel to the boundary between extortion and bribery, because often those who extort may leave their victims with material advantages from the transaction. This certainly happens in corrupt labor relations. 
banks, with personal zoos and palaces as prominent landmarks in a country where starvation was not unknown. ${ }^{17}$ From a modern Western perspective, the behavior of both these fin de siècle $e^{18}$ potentates was silly and immoral. But only one of the two was corrupt in the technical sense.

King Fahd was wasteful, stupid, and unempathetic with the several billions of petro-dollars that came under the control of the royal family of Saudi Arabia. But evidently the money he wasted was meant to be under Saudi law wholly under the control and personal dominance of the king. President-for-life Mobuto came to be known as "the man who stole a country" because of his conversion of public funds to private purposes: the extortion of bribes and the sale of publicly owned assets for private advantage were violations of the law of the nation he plundered. Mobuto was a criminal, while Fahd was merely a fool. In this sense, the definition of corruption that we favor depends on principles of local substantive law.

In one sense, this dependence on local principles might make the presence or absence of a corruption label morally trivial. Would Mobuto have been any less monstrous if a duly elected parliament had passed legislation declaring all income from mineral rights to be the personal property of Joseph Mobuto? When it is a violation of legal standards that transforms the use of power into a category of criminal behavior, many varieties of despotic behavior are properly regarded as non-criminal because those who fully dominate the institutions of government may be in the position to manipulate legal principles to avoid the label of corruption. In the vast majority of potential corruption situations, however, no such power to avoid legal conclusions will be present. And even most cases where the central government's leadership is involved in plunder, the legal standards by which the behavior can be classified as illegal have been left intact.

To require that the use of power be unlawful as a matter of the law of the place where the behavior occurs is to provide a neutral standard that can be used to separate corrupt behavior from permissible discretionary acts. Relying instead on non-local norms for judging the appropriateness of particular discretionary acts is difficult to justify on a principled basis. Indeed, the best comparative history of bribery defines the core concept as "an inducement improperly influencing the administration of a duty meant to be gratuitously exercised". Although the author of this definition displays some generalizing impulses (as when he asserts that bribery is everywhere shameful), as a conceptual matter, the meanings of the key terms in the definition-inducement, improperly, duty, and so on-cannot be discerned independent of the law and norms of a particular place. Thus, even if bribery is everywhere shameful and secretive, what counts as bribery is locally defined.

17. Transparency International, Global Corruption Report 2004 (Pluto Books 2004).

18. End of the Century.

19. See NOONAN, supra note 8 . 


\section{7 / On the Comparative Study of Corruption}

\section{B. Complexity and Corruption}

What are the conditions of social structure and social value that influence the rate and the varieties of corrupt behavior in a particular place? The comparative perspective might be a useful tool for addressing this kind of question, but care must be taken to specify the salient sub-questions. There is, for example, an important distinction between the conditions that increase the opportunities for corrupt acts and social features, which actually increase the rate of corrupt behavior. A major influence on the number and variety of potential cases of corruption is social and political complexity, with the number of opportunities for corrupt uses of power increasing as a function of the amount of power distributed throughout a social and political system and the complexity of restraints placed on the exercise of power in that system. The more complex an economic system, the greater the number of occasions when people will make important decisions that affect the property and interests of others. There are not only more different types of power in complex arrangements, there is a much greater tendency for the exercise of power to be constrained by the specialized roles of the people with access to it. When people put their savings under their mattresses, the primary custodians of the property are also its owners. In a society with banks, there are bank tellers and vice-presidents with power over the money of others, which is constrained by legal conditions. The opportunity to abuse power arises with the combination of physical control and legally limited power. The greater the complexity in a system, the larger the number of relationships of authorities with constrained power: toll takers, bank tellers, customs inspectors, tax auditors, mayors, and head waiters. In this sense, complexity in social and material relations is the mother of corruption.

The King Fahd example reminds us, however, that it is not merely the amount of property or power that determines the potential for corruption-it is also the constraints on its use. An absolute monarch cannot, by our definition, be a corrupt actor because there are no normative limits on his exercise of power. In the sense in which we use the term, it is not true that "absolute power corrupts absolutely." Rather, "absolute power" removes the constraints on power that make corruption possible when those constraints are not respected.

If opportunities for corruption expand with increases in complexity, do the rates of corruption also expand with an increase in the number of opportunities for exercising unlawful power? We suspect that a survey of developed and nondeveloped nations in the world at the turn of the 21 st century would reveal little evidence of a positive correlation between complexity and corruption. If anything, poor and simple societies tend to be more corrupt than rich and complex ones. ${ }^{20}$ In fact, when viewed from an external perspective, comparative judgments about corruption that business rating groups publish suggest that

20. Tina Rosenberg, The Taint of the Greased Palm, NY Times Magazine, Aug. 10, 2003. 
visible corruption is more often associated with more primitive levels of economic and political development. Conversely, complexity is associated with lower levels of corruption. ${ }^{21}$ Of course, there are many less-open societies in which limited capacity for investigation and communication causes even rampant corruption to go unmentioned in public media. However, that is not why complexity does not breed corruption; rather, most closed societies are not economically advanced.

There are at least three reasons why the rate of corruption does not grow as a function of the number of the opportunities for it to occur. First, many of the same technical processes that encourage the growth of complexity can be used to monitor the exercise of discretionary power and, thus, control corruption through direct observation and deterrence. Hence, accountability can also grow with complexity.

Second, increased complexity does not inevitably increase corruption because people learn social roles that impose an obligation of constraint. A culture of conformity with social roles of limited power is one important aspect of socialization in many complex modern societies. Being a responsible bank teller is learned behavior, and those who are socialized into roles with limitations on power will learn to respect and internalize the relevant rules of restraint. The material rewards for observing rules of restraint can be substantial, so can punishments for dereliction of duty. The incentives to conform are therefore great. In some less-developed societies, by contrast, less effort may have been expended trying to socialize people to internalize a commitment to restraint in the performance of their public roles, and fewer rewards are given those actors who do try to act with integrity.

There is a third reason why visible corruption might decrease in more complex societies-the evolution of forms of corruption into less visible behaviors to avoid the deterrents and preventions that grow with complexity. More complicated societies not only generate lower rates of corruption, but a smaller proportion of the corruption that is present in such systems will be visible and easily measured. Crude and visible forms of corruption disappear more quickly than subtle and hidden abuses. This is a form of natural selection that accompanies increased complexity. Thus, there is good reason to suppose that the "dark figure" of corruption will encompass a larger proportion of corrupt acts in complex and developed societies than in less-developed nations. As a result, the lower visibility of corruption in more complex societies is not just evidence of less crime, it also reflects the adaptive tendency to hide higher status offending in developed nations.

While cross-sectional comparisons of the variations between nations in the amount and variety of corrupt behavior are ambiguous evidence of causation,

21. See, for example, the cross-national Corruption Perceptions Indices that have been published by Transparency International every year since 1995; R. Hodess \& J. Banfield, and T. Wolfe, eds. Global Corruption Report, Berlin: Transparency International (2001). 
longitudinal analysis of the development of particular countries might better reveal patterns that would help to answer the following questions: Is there a recurrent pattern of change in the levels and types of corruption associated with various stages of economic or political development-a single "natural history" in which particular stages of development are associated with particular patterns of corruption? Or are there different evolutionary patterns associated with different cultural values that interact with stages of economic and political development? Are there some cultural conditions that retard the growth or accelerate the decline in levels of corruption, while other value patterns provoke it? If there are, what are these values and what are the magnitudes of their effects? And are there circumstances in which levels and types of corruption tend to be stable over long periods of time despite changes in other aspects of government and economy?

Similarly, how important is corruption to total economic activity and to the functions and responsiveness of the political system at different times and stages of development? If levels of corruption are much greater in some systems than in others of comparable economic development, how important are patterns of corruption in explaining the different prospects for economic growth and for the distribution of income? In particular, is corruption on the whole a regressive influence on income distribution, and are other types of crime more likely to reduce income inequality? If so, at what cost to economic growth?

Some features of social and economic development provide increased opportunities for many types of crime. Larger cities with efficient transportation systems encourage offenses of both stealth and force by creating the opportunity to come and go without fear of identification and detection. The same features of development facilitate fraud by enabling false identities to be assumed and dropped as people come and go.

If there are generalizations to be made about the criminological impact of increased complexity on corruption, we suspect that both trickery and corruption will be more prominent types of offending in wealthier and more complex social settings. This does not mean that rates of criminality of these types will actually increase as a number per thousand citizens or as a percentage of total economic activity, but rather that the proportion of all crime that is committed by fraud and corruption will go up with levels of social complexity and material wealth.

\section{Complexity and Types of Corruption}

Analysts of corruption in Western history argue that one corollary of the illegal nature of bribes is a universal penchant for secrecy. ${ }^{22}$ However, many patterns of governmental and political corruption are best classified as "open secrets." Indeed, strong circumstantial evidence of political favor-trading and

22. See NoONAN, supra note 8. 
dynastic favoritism to the family members of those in political power were all but acknowledged in regimes such as the Suharto government in Indonesia and the Marcos government in the Philippines, ${ }^{23}$ as well as among the government officials engaged in narcotics trafficking in places such as Mexico and Panama. The lack of a frightening deterrent should not motivate openness as long as visibility increases to some extent the risk of apprehension. To explain open corruption we need, instead, to search for positive utilities-benefits of openness-that reveal why even small risks may be thought worth taking.

Perhaps the phenomenon of the "open secret" is simply evidence of inefficient or inept criminality, so that the notoriety of corrupt behavior is a manifestation of the parties to the corruption failing to keep their shameful secrets hidden. But there are at least two other explanations of notorious corruption. The first is the "learning curve" notion mentioned previously. To the extent that there is real novelty in the restrictions on power that get imposed with governmental and economic complexity, relatively open patterns of corruption may take place because those who hold power use it without regard to relatively novel restrictions. President Mobuto-at some level-may have thought himself just as unconstrained in his personal use of his nation's treasure as did King Fahd with his obscene royal allowance. Under these circumstances, the open abuse of power might be a developmental stage that is quickly replaced by more cautious and prudent behavior as examples of the punishment and disgrace of the improprieties accumulated.

The problem with this "learning curve" explanation in the age of the jet-set is that so many intelligent and sophisticated people still seem prone to let favoritism, the conversion of vast sums of governmental resources, and the use of public power for personal gain become public knowledge. It is almost as if there were some benefit to corrupt behaviors being well known.

And there might be. Just as corruption is at its core a use of power, the visibility of corruption can be an advertisement of the corrupt actor's power. Favoring one's relatives and spending vast sums that can only have come from a public treasury are evidence of the great powers possessed by the actor. That public knowledge of the wrongful act may be a risk worth taking where it demonstrates the magnitude of the offender's power.

This instrumental and expressive value of "showing off" may be particularly pronounced when the corrupt act serves other favored social values such as helping the poor, ${ }^{24}$ being good to one's family, ${ }^{25}$ or serving the national honor.

One final motive for open corruption is as a way of asserting that the actor's power is not limited after all. The publicly corrupt act becomes a way of asserting its own legality. The openly corrupt activities may serve the offender as

23. Transparency International 2004 ranks these two leaders \#1 and \#2 in total corruption loss.

24. For example, Eva Peron.

25. Chaebol conglomerates in South Korea. 
evidence that his behavior is not really wrong. Certainly this is the dictator's usual defense when well-known abuses of power are the basis for later charges. Where this applies, it is a complete explanation for the utility of openness in the unlawful use of power for the offender, for it is only in the open defiance of a legal standard that the claim of rightfulness and therefore the validation of unconstrained power can be asserted.

\section{Corruption and Other Crimes}

It might also be useful in conducting comparative analyses over time or cross-sectionally to inquire about the relationship between rates of corruption and rates of other types of criminal offenses. The relationship between rates of various types of offenses over time and across different types of society has not been a major topic in theoretical or empirical criminology. The general assumption has been that environments with high rates of some types of criminal offenses would also have high rates of other varieties, but this type of analysis has usually been confined to various classes of crimes of stealth and force. ${ }^{26}$ The assumption is that many of the environmental features that provoke or repress one kind of offense will have the same kind of effect on other kinds as well. There is also, of course, the notion that periods and places with large numbers of persons willing to commit crimes will have high rates of all sorts of offenses. If the proximate cause of high crime rates is a large number of potential offenders, then the general level of all types of crime should reflect the level of potential offenders.

Once the relation between types of crime considers both corruption and crimes of stealth and force, assumptions about rates are complicated by the different distribution of criminal opportunities that exist for crimes of corruption. Corruption is an offense that requires power-either political or economic-for the meaningful opportunity to gain from its criminal use. Thus, not all of those who can employ force, stealth, or fraud for criminal purposes can resort to corruption. To the extent that crimes of force and stealth are concentrated in the least powerful elements of a society, there may be very little overlap between the most likely common criminals and those persons with the best opportunities to profit from corruption. Does this mean that there should be no significant relationship between rates of common offenses and rates of corruption? Probably not.

Even if particular offenders can not or do not commit both types of offenses, the environmental conditions that foster or discourage common and corruption offenses might still generate systematic relationships between corrupt and common crimes. If the populations of potential offenders are distinct, there should be no substitution between common and corrupt offenses. But if there are

26. ZIMRING \& HAWKINS, supra note 2, at ch. 2. 
environmental conditions, such as high or low tolerance of dishonesty, or levels of effort or efficiency in detection and prosecution of offenses, that have a common influence on different types of crime, then one would expect rates of non-corruption and corruption offenses to rise and fall together.

There may also be social conditions that favor some forms of criminality and disfavor others. In Asia, for instance, Japan exhibits middling levels of many types of corruption offenses, but has extremely low rates of crimes of force and stealth. ${ }^{27}$ Conversely, Thailand has higher levels of both lethal violence and corruption, ${ }^{28}$ while Singapore has more lethal violence but substantially less corruption. In Europe, Italy has high levels of corruption and high homicide rates (at least by European standards), while the United Kingdom has lower rates of both corruption and homicide. And in the United States, Louisiana has high levels of corruption and lethal violence, while Hawaii has high levels of corruption, but low levels of violence. ${ }^{29}$ As these examples illustrate, different types of crime often move independently of one another. The comparative study of crime and corruption may help to identify patterns within that variation.

\section{CORRUPTION AND THE PROBLEMATICS OF WHITE-COLLAR CRIME}

The extraordinary history of the study of "white-collar crime" can inform the analysis of corruption in two respects. First, it provides a cautionary tale of how problems of definition and classification can promote confusion and inhibit research. Second, some of the important themes that characterize writing about white-collar crime turn out to be at the core of corruption as a crime type as well. Students of corruption can learn from the definitional problems of the whitecollar category at the same time that the focus on the abuse of power in corruption can teach important lessons about one subcategory of white-collar crime with distinctive characteristics.

Stanton Wheeler ${ }^{30}$ began his analysis of definitional issues in white-collar crime by quoting E. A. Ross's comment about the perfidy of "the man who picks pockets with a railway rebate, murders with an adulterant instead of a bludgeon, burgles with a 'rake off' instead of a jimmy, cheats with a company prospectus instead of a deck of cards" ${ }^{31}$ The problem with this rhetorical assemblage of the

27. J.M. Schlessinger, Shadow Shoguns: The Rise and Fall of Japan's Postwar Political MACHINES (1997).

28. P. PhONGPAICHIT AND S. PIRIYARANGSAN, CORRUPTION AND DEMOCRACY IN ThaILAND (Silkworm Books 1994).

29. Compare T. BRIDGES, BAD Bet ON THE BAyOU: THE Rise of GAMBling IN Louisiana AND THE FALL OF GOVERNOR EDWIN EdWARDS (1999) with G. COOPER AND G. DAVIS, LAND AND POWER IN HAWAII: The Democratic Years (1990); and Federal Bureau of INVESTIGATIONS, UNIFORM Crime RePORTS: CRIME IN THE UNITED STATES (2003), available at http://www.fbi.gov/ucr/03cius.htm.

30. Stanton Wheeler, White Collar Crime: History of an Idea, in ENCYCLOPEDIA OF CRIME AND JUSTICE 1653 (Macmillan 1983).

31. E. ALSWORTH RosS, SIN AND SOCIETY: AN ANALYSIS OF LATTERDAY INIQUITY (1907). 
sins of the powerful is the lack of analytic precision in identifying the agency of criminal harm. How, for example, does one "pick pockets with a railway rebate"? Such metaphors are both a wonderful tool for condemning conduct and a step away from rigor in defining the wrongfulness and the criminal agency that characterize the offending.

The first formal attempt to define white-collar crime was provided by Edwin H. Sutherland, the author of the concept. According to Sutherland, "White-collar crime may be defined approximately as a crime committed by a person of respectability and high social status in the course of his occupation." But why is the social status of the offender important? If it was to demonstrate that crime is not solely the product of poverty, then why was the job-related aspect also deemed important? And if there were supposed to be any distinctive elements attached to the job-related aspect of this definition of white-collar crime, what were they?

Moreover, Professor Wheeler says that Sutherland's definition and his empirical focus diverged from the start:

His book was devoted, however, to the crimes of organizations not of persons... thus a firm basis for ambiguity had been laid. Those following Sutherland sometimes focused on persons of high status, sometime on occupation, and sometimes on corporate bodies.

The "crimes" that Sutherland counted included both violations of regulatory standards and civil contract cases. Although organizational offenses are an important criminological category, ${ }^{32}$ they are only one part of the white collar category in all of the usual definitions. For this and other reasons, Wheeler claimed in 1983 that "the concept of white-collar crime is in a state of disarray"." Nothing in subsequent analysis has clarified the core conception.

There are important parallels in the definitional problems found in the whitecollar and corruption categories. First, the symbolic or adjectival character of some definitions of both terms has generated conceptual confusion. Just as the need to stigmatize the corrupt official or influence peddler has blurred definitional boundaries in corruption, so does the metaphor of "picking pockets with a railway rebate" in white-collar crime owe none of its rhetorical power to precision. Denunciations of white-collar crime "reflect a concern for the weakening of the social fabric created when people in privileged positions destroy trust by committing crimes". ${ }^{34}$ Although the same language can be used to describe popular disgust with corruption, the cost of such broad rhetorical sweeps has been substantial. Most importantly, the loose and denunciatory usage

32. M. TONRY \& A.J. Reiss, JR., eds., Beyond the LAw: CRime in COMPLEX ORganizations, Crime AND JUSTICE: A REVIEW OF RESEARCH (1993).

33. Wheeler, supra note 30.

34. Id. 
of both of these terms hampers the search for conceptual clarity and analytical utility.

In fact, we go even further to suggest that one reason for special public concern with white-collar crime can be found in the technical conception of corruption that we urge-the abuse of power. Whether combined with fraud or merely concealed, the essence of corruption is the misuse of power (and this is also what Professor Wheeler would regard as the misuse of privilege). In some settings, the misuse of power is manifest as classic organizational offenses, while in other settings, organizations are the primary victims of corrupt offenses by individuals or groups. In either case, it is not merely a crime by a powerful person that invites special condemnation; it is the criminal misuse of power.

The parallels between white-collar crime and corruption provide another context in which to reconsider the question of whether personal gain should be a definitional requirement of criminal corruption. In the annals of white-collar crime, when combinations to retrain prices, for example, are discovered, there is no reason to worry about whether those who fix prices were only operating for the benefit of the corporations they represented or whether they personally would gain from the artificially high prices. Certainly, the General Electric heavy equipment conspiracies would have been just as socially injurious if its only beneficiaries had been the corporation. So why require personal gain as an element of the definition?

It is no answer to this that personal advantage can always be found through creative contortions in cases where organizations will benefit from restraint of trade. The essence of the anti-social nature of price-fixing depends in no obvious way on whether the corporate conspirators obtained raises or stock options. If the corrupt bank teller or government official passed all her material gains to favored friends, how would that diminish the corruption?

Our focus on the misuse of power in both corruption and white-collar crime may also help to distinguish degrees of wrong in notorious behavior by public officials. The mayor of Washington, D.C., Marion Barry, was caught ingesting crack cocaine (after the standard set of public denials). Barry's drug dependency certainly compromised his ability to serve as a public official, but the degree of public blame in this case was sufficiently tempered so that, even after his drug treatment, Barry was deemed a credible candidate in the next election. When he was president, Bill Clinton had a sexual relationship with an intern and lied about it. What may separate these offenses from the Watergate scandal and the Daniel Ellsberg burglary case is the distinction between crimes involving powerful people and the criminal misuse of power. It is not merely the misbehavior of those with power that generates special condemnation; it is when power becomes the instrument of criminality that deeds are deemed most blameworthy. This, more than class resentment, may explain the angry response to the symbolism of some forms of white-collar crime and corruption. What is distinctively modern and threatening in the criminal use of power are the modern innovations and mechanisms that are utilized to achieve criminal ends. Whether this is a part of 
crimes against organizations or of crimes on behalf of organizations, it turns the tools of modernity against the public welfare and elicits especially intense disapprobation.

\section{CONCLUSION}

The central principle of this article is that corruption is the criminal misuse of power. This feature of corruption as a crime suggests that it is an offense that will be committed more often than others by persons of higher social and economic status (who hold the power that generates the potential for corruption). Because the criminal misuse of social or political power can be viewed as an abuse of trust, there is a reason to predict that corrupt offenders will be viewed as more blameworthy than those who take by deception or stealth. This same tendency to condemn the misuse of power may explain some of the passion in the criminological discourse about white-collar crime. 